\title{
THE INFLUENCE OF THE 1992-1993 EL NIÑO ON THE REPRODUCTIVE BIOLOGY OF Scomber japonicus peruanus (JORDÁN \& HUBB, 1925)
}

\author{
Hilda Caramantin-Soriano ${ }^{\text {; Luz Amelia Vega-Pérez }}{ }^{1}$ and Miguel Ñiquen ${ }^{2}$ \\ ${ }^{1}$ Instituto Oceanográfico da Universidade de São Paulo \\ (Praça do Oceanográfico, 191, 05508-120 São Paulo, SP, Brasil). \\ ${ }^{2}$ Instituto del Mar del Perú \\ (Apartado postal 22 Callao, Perú)
}

Corresponding authors: hildacs@hotmail.com; lavega@usp.br

\begin{abstract}
A B S T R A C T
The influence of the 1992-1993 El Niño events on the reproductive behavior of the Scomber japonicus peruanus (Chub mackerel) was studied from samples collected monthly, along the Peruvian coast $\left(3^{\circ} 23^{\prime} \mathrm{S}-14^{\circ} 00^{\prime}\right.$ 'S), from January 1990 to December 1993 . The monthly variation of the gonadosomatic index and the frequency of the periods of gonad maturation evidenced that the spawning of the species occurred all year long, being more intense in summer. The values of the gonadosomatic index were higher during the occurrence of the 1992-1993 El Niño, while the body weight and gonad weight decreased. Regarding the condition factor, its values decreased in females over $35 \mathrm{~cm}$ in fork length.
\end{abstract}

\section{R E S U M O}

A influência do evento El Niño 1992-1993 no comportamento reprodutivo de Scomber japonicus peruanus (cavalinha) foi estudada a partir de amostras coletadas mensalmente, ao longo do litoral peruano $\left(3^{\circ} 23^{\prime} \mathrm{S}-14^{\circ} 00^{\prime} \mathrm{S}\right)$, de janeiro de 1990 a dezembro de 1993 . A variação mensal do índice gonadossomático e a frequiência dos estágios de maturação gonadal evidenciaram que a desova da cavalinha ocorreu o ano inteiro, sendo mais intensa no verão. Os valores do índice gonadossomático foram mais elevados durante o evento El Niño, mas, em contraposição, as fêmeas apresentaram peso menor. Os dados mostraram que o fator de condição diminuiu em fêmeas com mais de $35 \mathrm{~cm}$ de comprimento furcal.

Descriptors: Scomber japonicus peruanus, Gonadal maturation, Gonadosomatic index, Condition factor, El Niño event, South Pacific.

Descritores: Scomber japonicus peruanus, Maturação gonadal, Índice gonadossomático, Fator de condição, El Niño, Pacífico Sul.

\section{INTRODUCTION}

El Niño Southern Oscillation (ENSO) is the largest coupled ocean-atmospheric episodic phenomenon in the Pacific Ocean. During El Niño event, the seawater temperature changes substantially in space and time as the result of large-scale fluctuations in atmospheric pressure, sea level, and current patterns (MORON, 2000; LU et al., 2001). The warming episodes that appear to be part of the El Niño event are of great interest because of their impact on both fisheries and weather, and have been the focus of considerable study (WILCZAK et al., 2007).

The oceanographic changes associated with El Niño events off the Peruvian coast have included intrusions of oceanic low nutrient, warmer and more oxygenated waters into coastal areas. These changes

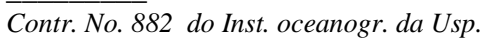

are responsible mainly for the reduction in the extent of the productive zone and alterations in the "normal" seasonal regime (ESCRIBANO et al., 2002) which has affected the dynamic population of the pelagic fishes, producing significant changes mainly in their abundance and distribution patterns, reproductive failure and mortality (ZUZUNAGA, 1985; ARANCÍBIA; NEIRA, 2002; ÑIQUEN; BOUCHON, 2004).

Small pelagic fishes represent about 20-25\% of the total annual world fisheries catch (FAO, 2007), and they are characterized by their short life span, high fecundity and by the fact that some spawn all year round. These biological characteristics make them highly sensitive to environmental forcing and extremely variable in their abundance (ALHEIT, 2002).

Scomber japonicus peruanus (Chub mackerel) is one of the small pelagic fish, more 
frequent and abundant in the South Pacific Ocean, especially in the coastal waters of Costa Rica, Equador, Peru and Chile. It is primarily a coastal species, found from the surface down to $300 \mathrm{~m}$ depth (COLLETTE; NAUEN, 1983). In the Peruvian economy the species is important for their abundance and commercial value, being utilized mainly as raw material for the production of fish meal and as a food resource by the population (OLDEPESCA, 1986; IMARPE; ITP, 1996). The commercial exploitation of Scomber japonicus peruanus started in the 1960s. The catches of the species increased steadily in the early $1970 \mathrm{~s}$ when it reached 410,302t, decreasing to $362,000 \mathrm{t}$ in the 1980s. A progressive reduction of this resource occurred in $1992(8,119 t)$, probably due to the continuous exploitation, but peaked again in 1998 (380,526t) (ÑIQUEN; BOUCHON, 1995, 2004). However, landings declined in the period 2000-2003 and it has persisted since then, indicating that in these period $S$. japonicus peruanus was over-exploited and nearing its maximum capacity (CARAMANTÍNSORIANO et al., 2008). Therefore, biological information such as annual reproductive cycle is indispensable to effectively manage stock sizes of the species.

Published literature has dealt almost exclusively with taxonomy, distribution and some aspects of the Chub mackerel biology (MINANO; CASTILLO, 1971; KOTLYAR; ABRAMOV, 1982; MENDO, 1984; CARAMANTÍN, 2006). However, information about the species' reproductive biology, crucial for their fishery management is still insufficient (PEÑA et al., 1986; BUITRON; PEREA, 1998; CARAMANTÍN, 2001) and the factors that possibly affect the reproductive cycle of the Chub mackerel, during climatic-oceanographic events such as El Niño, have not yet been described.

The goal of the present study is to provide information about the influence of the 1992-1993 El Niño event on the reproductive biology of S. japonicus peruanus on the Peruvian coast, South Pacific.

\section{Material and Methods}

The reproductive biology of $S$. japonicus peruanus "Chub mackerel" was studied based on 6,091 females obtained from commercial landings along the Peruvian coast $\left(3^{\circ} 23^{\prime} \mathrm{S}-14^{\circ} 00^{\prime} \mathrm{S}\right.$ and $76^{\circ} \mathrm{W}$ $82^{\circ} \mathrm{W}$ ), from January 1990 to December 1993 (except in July 1990 and December 1991 and 1992), within the project "Tracking of pelagic resources off the Peruvian coast", which is being carried out by the "Instituto del Mar del Perú - IMARPE" (Fig. 1). The specimens were caught by an industrial purse seine vessel. The Sea Surface Temperature (SST) was concomitantly recorded in each of the sampling areas with a bucket thermometer.
A random sample of approximately $40 \mathrm{~kg}$ gwas taken from a vessel before the catch, sorted and landed, the specimens being placed in an ice box. In the laboratory, all the specimens were measured (nearest $\mathrm{cm}$ ) and weighed (nearest $0.01 \mathrm{~g}$ ). For each female, the fork length, total weight and eviscerate weight were recorded. The ovaries were removed, weighed (nearest $0.01 \mathrm{~g}$ ), measured and examined macroscopically to assess their maturity stage in accordance with the scale proposed by Johansen (1919):

I. Virginal: ovary reddish, slender and transparent.

II. Juvenile: ovary reddish with some small oocytes, visible only under the stereomicroscope.

III. Initial maturation: ovary reddish with opaque oocytes in maturation stage.

IV. Middle maturation: ovary orange and with opaque oocytes in maturation stage.

V. Ripe: ovary yellowish with large and rounded oocytes.

VI. Spawning: ovary with translucent oocytes released through genital aperture.

VII. Partially spawned: ovary flaccid and with a few oocytes.

VIII. Spent: ovary reddish and with degenerate oocytes.

The reproductive period of $S$. japonicus peruanus was established analyzing the Gonadosomatic Index values (ANDERSON; GUTREUTER, 1983), the monthly relative frequency of the gonadal maturity stages (ARRIAGA; COELLO, 1984) and the Condition factor (ARANCIBIA et al., 1994).

The Gonadosomatic Index (GSI) was calculated using the equation: $\mathrm{GSI}=\left(\mathrm{W}_{\mathrm{g}} / \mathrm{W}_{\mathrm{t}} \cdot 100\right)$, where: $\mathrm{W}_{\mathrm{g}}=$ gonad weight $(\mathrm{g}) ; \mathrm{W}_{\mathrm{t}}=$ body weight $(\mathrm{g})$. Thus were the monthly mean Gonadosomatic Index values obtained.

The Condition factor was estimated using the formula: $\mathrm{KC}=\left[\left(\mathrm{W}_{\mathrm{t}}-\mathrm{W}_{\mathrm{g}}\right) / \mathrm{C}_{\mathrm{f}}{ }^{\mathrm{b}} .100\right]$, where: $\mathrm{KC}=$ corrected condition factor; $\mathrm{W}_{\mathrm{t}}=$ total body weight $(\mathrm{g})$; $\mathrm{W}_{\mathrm{g}}=$ gonad weight $(\mathrm{g}) ; \mathrm{b}=$ angular coefficient of length-weight relationship. Thus, were the monthly mean values of the corrected condition factor obtained.

The monthly changes in mean Gonadosomatic Index were analyzed by one-way variance analysis, and by Tukey's multiple ranges test (ZAR, 1999). Analysis of covariance (ANCOVA) was used to determine whether there was any significant correlation between the mean values of GSI and SST.

The length-weight relationship of $S$. japonicus peruanus females was estimated for the whole period of the study using the equation: $\mathrm{W}_{\mathrm{t}}=\mathrm{a}$ $\mathrm{C}_{\mathrm{f}}{ }^{\mathrm{b}}$, where the parameters $\mathbf{a}, \mathbf{b}$ were obtained by least squares regression using the $\log$ transformed weights and sizes. 


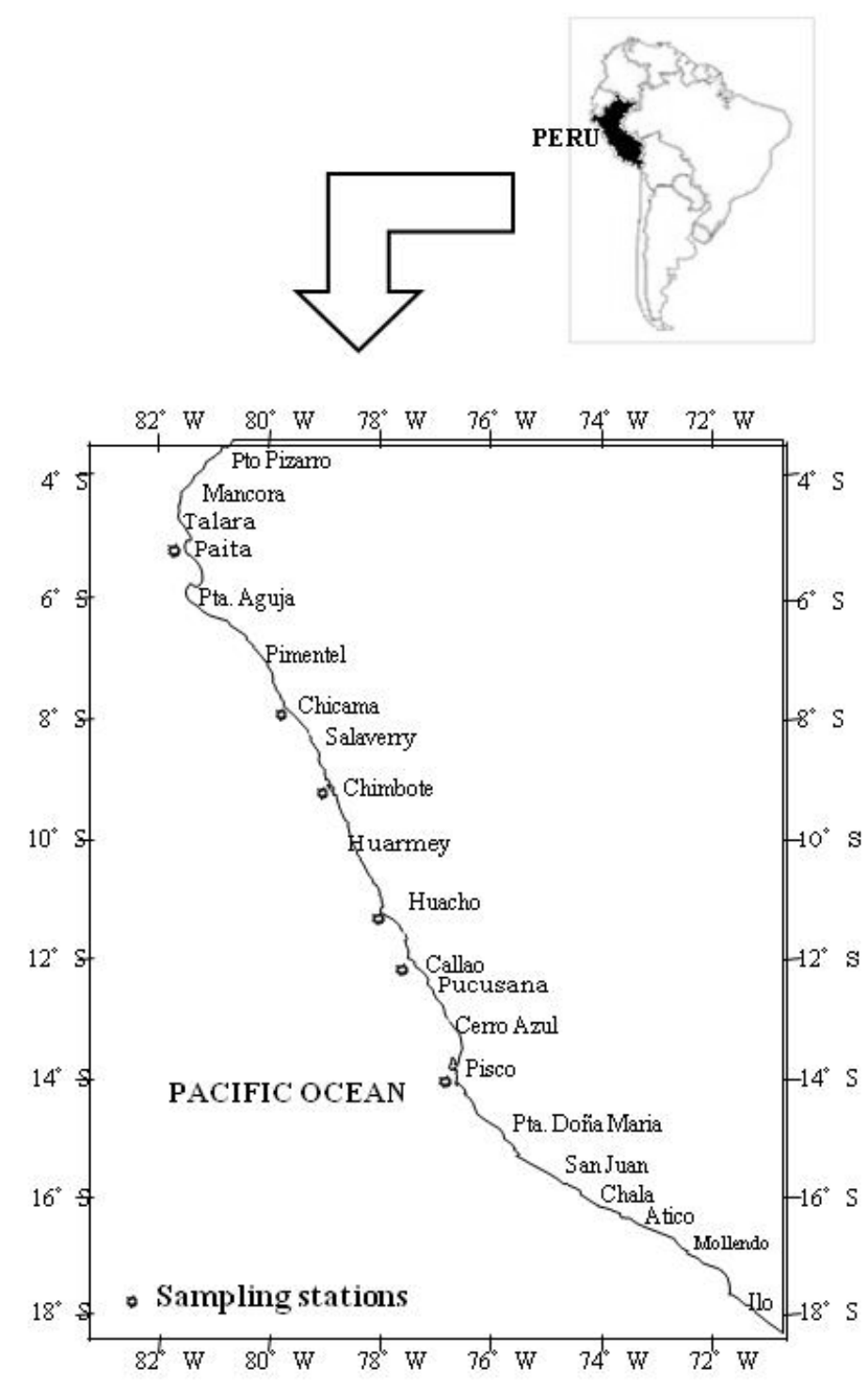

Fig. 1. Map showing the sampling stations along the Peruvian coast.

\section{RESULTS}

The Sea Surface Temperatures (SST) recorded along the Peruvian coast during the period 1990-1993 ranged from 16.27 (August 1990) to $24.73^{\circ} \mathrm{C}$ (March 1992). Higher values of SST were registered from January to April 1992 and February to March 1993, evidencing the occurrence of El Niño event in these two years. The lowest values of SST were found from August to October 1990, 1992 and October 1993 (Fig. 2).

The gonad maturity stages of $S$. japonicus peruanus females showed that specimens at stage III were absent in summer 1993, but frequent in all the autumns $(7.0 \%-24.25 \%)$. In contrast, females at stage IV were more frequent in winter 1990 (24.21\%), summer $1991(10.59 \%)$ and spring 1992 $(12.10 \%)$ and $1993(43.60 \%)$, while females at stage V occurred in the summer $(15.53 \%-42 \%)$ and winter (10.60\%-27.37\%) from 1990 to 1993 . The results showed that females at stage VI also had maximum frequency in the summers $(22.66 \%-68.10 \%)$, whereas the frequency of females at stage VII $(3.70 \%$ $13.41 \%)$ and stage VIII $(0.91 \%-8.0 \%)$ decreased (Fig. 3). 


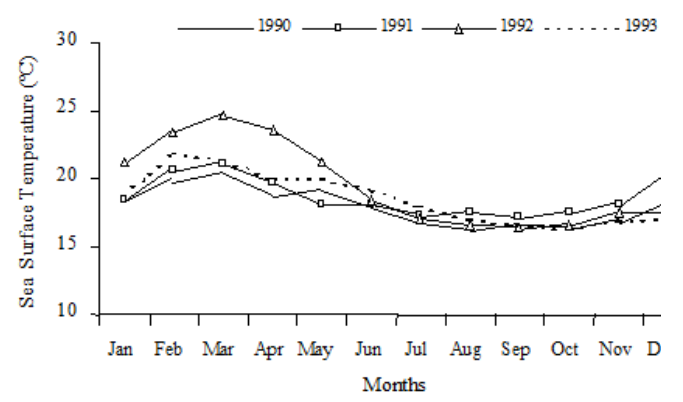

Fig. 2. Monthly values of the sea surface temperature along the Peruvian coast from 1990 to 1993.

The mean Gonadosomatic Index of $S$. japonicus peruanus females during the period of the study varied between 1.30 and 11.80 , the higher values being obtained from February to March 1992 (summer), March to April 1993 (early autumn), February 1990 and March 1991 (summer). The mean GSI values decreased sharply in the other months attaining the lowest values in May and November 1991, and from November to December 1990. The peaks of the mean GSI values registered suggest that the reproductive activity of $S$. japonicus peruanus females was more intense during the summer season (Table 1). On the other hand, the one-way ANOVA $(P<0.001)$ showed significant differences in the mean GSI values among months. However, Tukey's post hoc pairwise comparisons showed that the mean GSI values in February and March were significantly different from those of the other months of the years concerned $(P<0.001)$. Furthermore, the data obtained also evidenced that there was significant correlation between mean GSI values and SST $(p<0.05)$, this fact becoming evident during the occurrence of the 19921993 El Niño events (Fig. 4).

Đ Summer

- Autumn $₫$ Winter $\square$ Spring
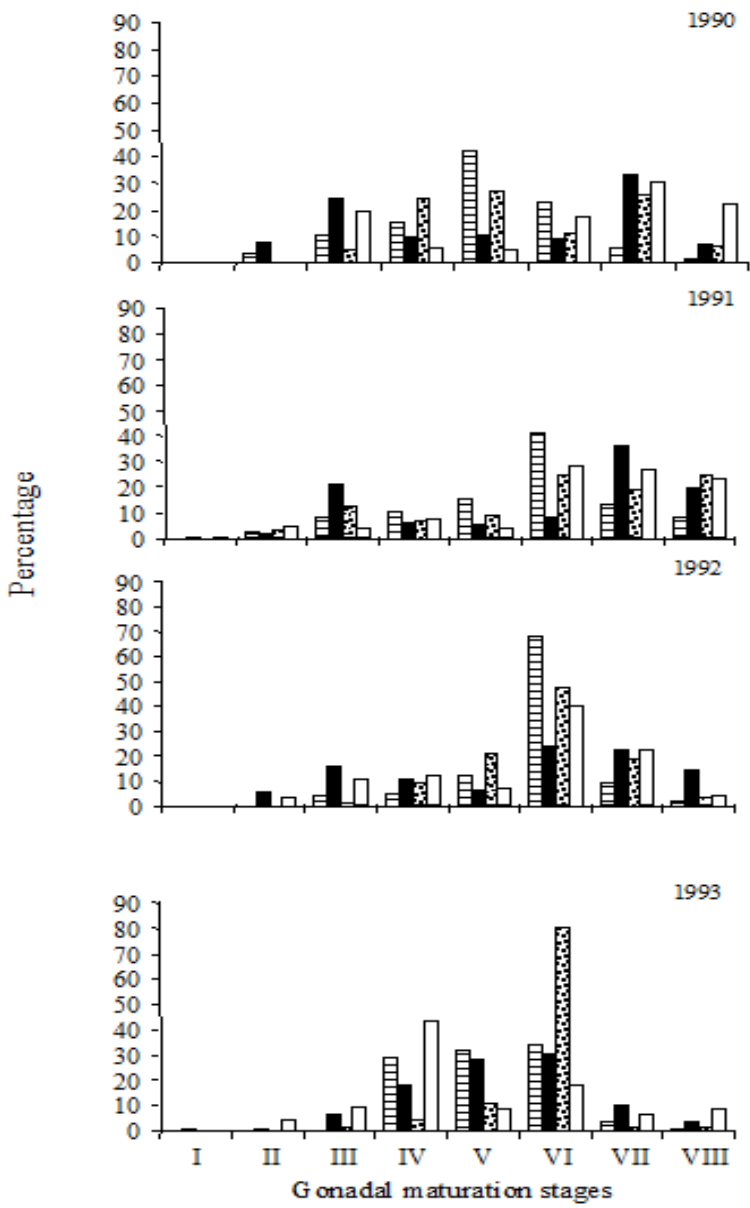

Fig. 3. Seasonal distribution of gonadal maturation stages of $S$. japonicus peruanus females from 1990 to 1993. 
Table 1. Monthly mean gonadosomatic index values of $S$. japonicus peruanus females from 1990 to 1993.

\begin{tabular}{ccccc}
\hline \hline Months & 1990 & 1991 & 1992 & 1993 \\
\hline January & 8.80 & 3.70 & 7.30 & 6.60 \\
February & 10.10 & 7.30 & 11.80 & - \\
March & 8.10 & 9.50 & 9.60 & 11.0 \\
April & 5.70 & 2.60 & 5.90 & 9.40 \\
May & 1.60 & 1.30 & 3.20 & 4.0 \\
June & 4.0 & 1.40 & 2.90 & 4.60 \\
July & - & 2.50 & 3.40 & 5.30 \\
August & 4.60 & 2.90 & 3.50 & 3.80 \\
September & 3.30 & 5.30 & 3.90 & 6.30 \\
October & 3.90 & 3.90 & 3.80 & 5.60 \\
November & 1.50 & 1.30 & 3.70 & 5.90 \\
December & 1.50 & 4.50 & - & - \\
Mean & 4.83 & 3.85 & 5.36 & 6.25 \\
Standard & 3.03 & 2.52 & 2.98 & 2.31 \\
deviation & & & & \\
\hline
\end{tabular}

In the present study, the fork length of $S$. japonicus peruanus females ranged between $19 \mathrm{~cm}$ and $39 \mathrm{~cm}$. The mean corrected condition factor $(K C)$ varied from 1.10 to 1.32 , the lower values being obtained in the summers 1990-1993 (Fig. 5). It was also verified that the condition factor for length interval was directly related to fork length, although the $K C$ values in females over $35 \mathrm{~cm}$ in fork length had decreased mainly during El Niño events (Fig. 6).

On the other hand, the length-weight relationship of $S$. japonicus peruanus females was expressed by the equation: $\mathrm{Wt}=0.0070 * \mathrm{C}_{\mathrm{f}}{ }^{3.18}$, with a coefficient of correlation (r) of 0.91 (Fig. 7). The results also showed that the weight of the females decreased by between $2 \%$ and $7 \%$ in the years 1992 and 1993, as compared with that of the years 1990 and 1991 (Fig. 8).
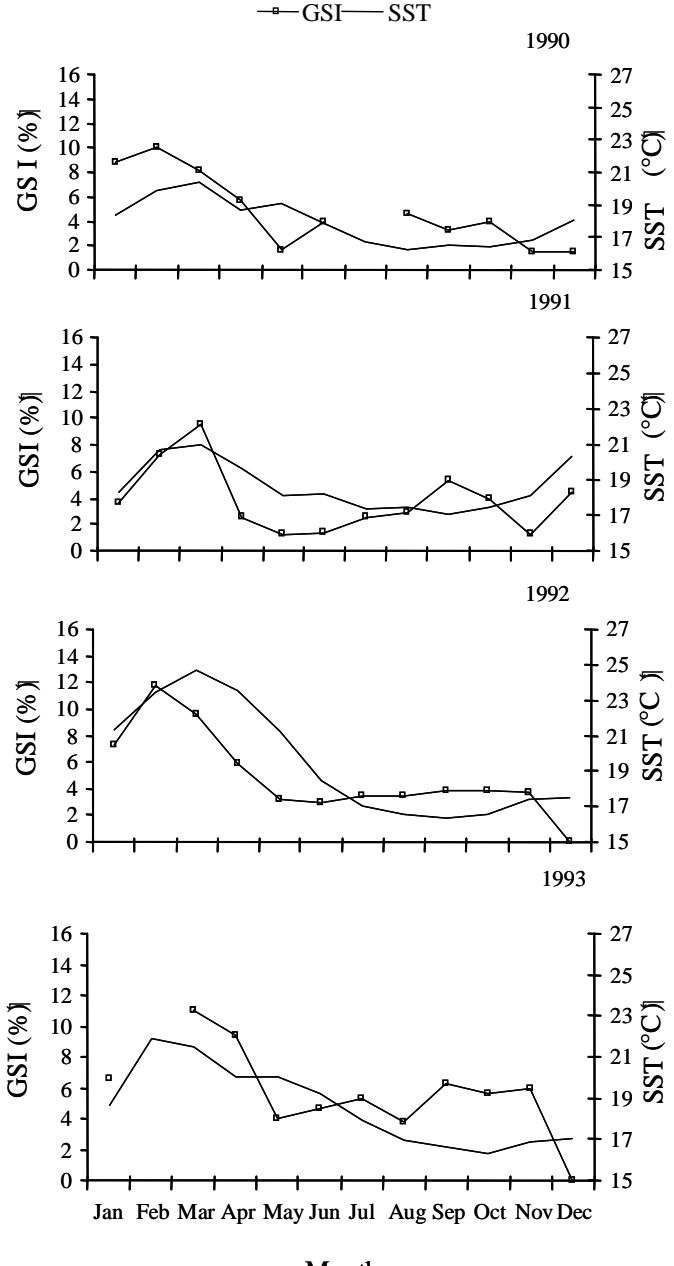

Months

Fig. 4. Monthly variation of the sea surface temperature and mean gonadosomatic index of $S$. japonicus peruanus females caught from 1990 to 1993 years along the Peruvian coast. 


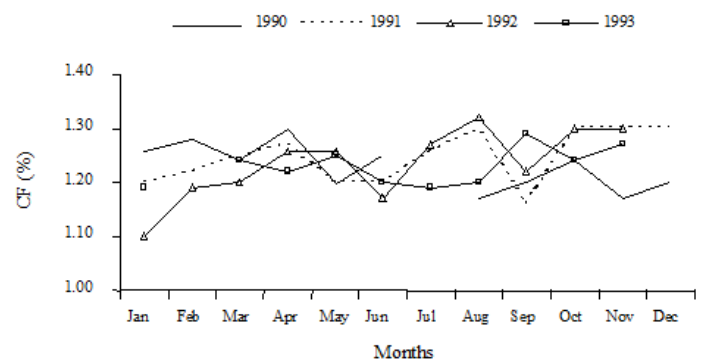

Fig. 6. Monthly variation of the mean corrected condition factor by lengths of $S$. japonicus peruanus females caught from 1990 to 1993 on the Peruvian coast.

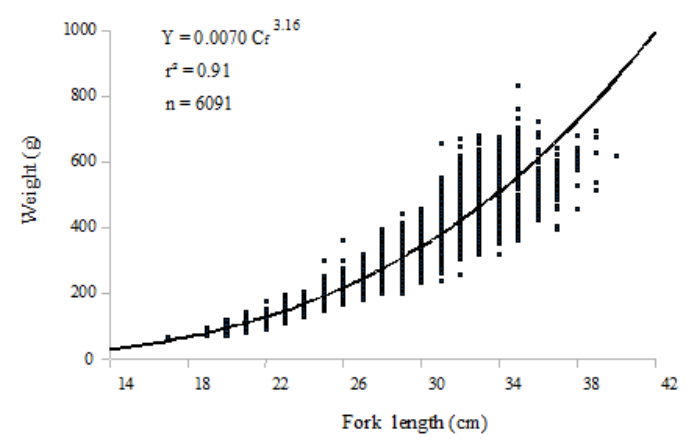

Fig. 8. Monthly variations of average weight of $S$. japonicus peruanus females from 1990 to 1993.
Fig. 5. Monthly variation of the mean corrected condition factor of $S$. japonicus peruanus females obtained from 1990 to 1993.

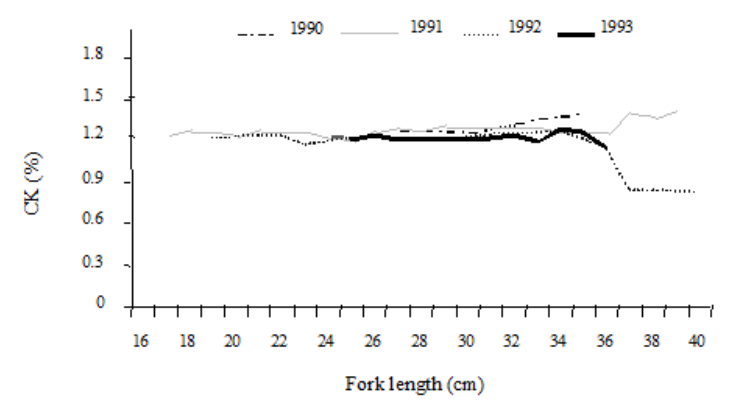

Fig. 7. Length-weight relationship of S. japonicus peruanus females obtained in the period 1990- 1993.

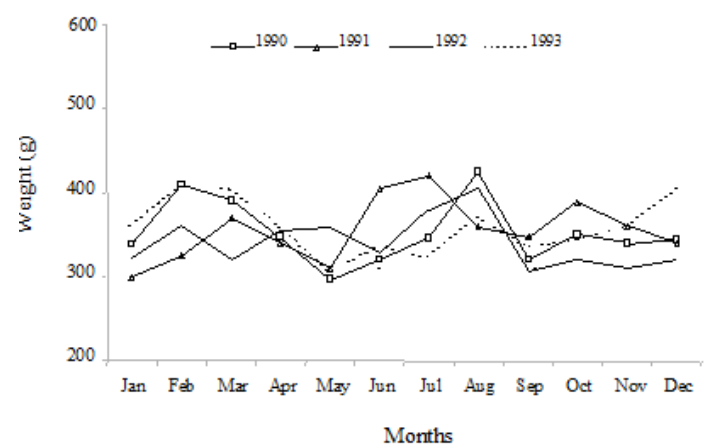




\section{Discussion}

The identification of the fishes' reproductive cycle may be made by the development of the gonads (WEST, 1990). Studies of fish reproduction based on the macroscopic classification of gonads' maturity stages have been used successfully to determine the spawning pattern and in the monitoring of fish stocks (MACKIE; LEWIS, 2001; PLAZA et al., 2007). The spawning strategy may be classified by the number of spawning episodes during the season, with some species spawning only once, or for a very short period, while others will spawn several times during the spawning period (MADDOCK; BURTON, 1998. CARAMANTÍN (2001) and BUITRON;PEREA (1998), based on the macroscopic and microscopic analysis respectively of the $S$. japonicus peruanus gonads concluded that the species is a partial spawner with constant gonadic activity. On the Peruvian coast, great numbers of $S$. japonicus peruanus females with ripe and spawning ovaries (stages V and VI) are frequently found in the north and middle regions, their spawning activity being more intense in the summer (SANTANDER; FLORES, 1983; CARAMANTÍN, 1998). A similar pattern was reported by GLUYASMILLÁN; QUIÑONEZ-VELÁZQUEZ (1997) for $S$. japonicus, which also spawns mainly during summer, in the Gulf of California. In the Argentine region, however, S. japonicus has its spawning period mainly in spring (PERROTA et al., 2001). In the present study, Chub mackerel females at stages V and VI were commonly found during the summer periods of 19901993, indicating intense spawning activity in this season. The results obtained also showed that $S$. japonicus peruanus is a partial spawner. On the other hand, Gonadosomatic index values are generally used as indicators of gonad size relative to body size, because changes are thought to be related to spawning cycles as well as to the duration of reproductive seasons (HAY; OUTRAM, 1981). Changes in GSI may therefore, indicate the onset and duration of the spawning season. Peak spawning or initiation of peak spawning is indicated by a rapid increase in GSI values (KAINGE et al., 2007). The results obtained in the present study confirm the reported by those authors, since higher values of the mean GSI of $S$. japonicus peruanus were found during the summer season (8.1-11.8).

The fecundity of pelagic fishes has been characterized by periods of lower and higher breeding intensity. These fluctuations have been related to changes in ambient temperature, salinity, oxygen, migration activity and food availability (MUNRO et al., 1990; WOOTTON, 1998; LIU et al., 2001; NARIMATSU et al., 2007). According to Jian et al. (2003) and Palomares-García et al. (2003), temperature can play an important role in the reproductive biology of marine fishes, because it affect the metabolic rate and reproductive cycle.

Higher temperature variations due to El Niño events influence the distribution, abundance, reproduction and recruitment of the pelagic species (BORJA et al., 2002; MCFARLANE et al., 2005; RIASCOS, 2006). According to Anda-Montañez et al. (2004), the spatial-temporal pattern of Thunnus albacares in the eastern tropical Pacific seemed not to be strongly affected by a moderate El Niño event. When El Niño was strong, as it was in 1982-1983, the productivity of the area was significantly reduced and this produced a remarkable impact on the tuna fishery. Palomares-García et al. (2003) reported that the reproductive activity of Sardinops caeruleus in Magdalena Bay (Mexico) was strongly affected by the 1997-1998 El Niño events.

The anomalous warming of the water on the Peruvian coast during the 1987 El Niño episode, contributed to prolonging the spawning period of $E$. ringens (PEÑA; CARRASCO, 1989). Recently, Niquen and Bouchon (2004) reported that the reproductive activity of the species $S$. sagax sagax, $S$. japonicus peruanus and Anchoa nasus was more intense, during El Niño events, in this region. The species $S$. japonicus peruanus normally spawns with more intensity in summer (from January to March), with a short spawning period between winter and spring (MENDO, 1984; CARAMANTÍN, 2006). According to Santander and Zuzunaga (1984), during the 1982-1983 El Niño phenomenon, the reproductive period of $S$. japonicus peruanus was prolonged and the spawning more intense during January and April. The results obtained in the present study are in accordance with those reported by those authors, and suggest the influence of 1992-1993 El Niño events on the reproductive activity of the Chub mackerel.

Nevertheless, it seems that changes in the water temperature structure alone cannot directly account for the changes observed in the reproductive biology of some fishes. Other factors, such as poor feeding conditions must also play an important role. Reduction of the body weight of $S$. sagax sagax, $T$. murphyi and $S$. japonicus peruanus was observed when the Peruvian coast was affected by the 1983 El Niño event. Sánchez et al. (1985) and Peña and Carrasco (1989) attributed the decrease of the body weight of $S$. sagax sagax to stress and to the small quantity of food available during the occurrence of the 1987 El Niño episode. Loss of body weight was also registered in $T$. picturatus murphyi during the occurrence of the 1982-1983 and 1997-1998 El Niño events along the Peruvian coast (DIOSES et al., 2002).

According to Martínez et al. (1985), in some fishes the loss of body weight can be attributed in part to prolonged spawning. Caramantín (2001) ascertained that during the 1997-1998 El Niño, considered one of 
the strongest events ever registered in Peruvian waters, $S$. japonicus peruanus had their spawning period prolonged, accompanied by a loss in body weight. In the present study, this species also exhibited prolonged spawning and a decrease in body and gonad weight during the 1992-1993 El Niño events, suggesting the influence of this phenomenon on the reproductive biology of the Chub mackerel.

The condition factor is one of the principal parameters for the evaluation of the general conditions of fish, frequently being associated with their reproductive cycle (VAZZOLER, 1996; SOUZACONCEIÇÃO et al., 2005). According to Claereboudt et al. (2005) and Plaza et al. (2007), the condition factor and the gonadosomatic index are quantitative indicators utilized in the evaluation of the reproductive biology of pelagic species. Silva et al. (2005) reported that the CK of Scomberomorus brasiliensis from Brazilian waters can reach higher values before its spawning peak. The results obtained in the present study confirm the report of those authors, since higher values of the condition factor of $S$. japonicus peruanus females were also found before the reproductive activity of the species. Maddock and Burton (1999) related that the condition factor of the species $H$. platessoides from the Grand Bank of Newfoundland was generally low at the onset of the spawning season, probably due to the mobilization of the somatic energy reserves needed for reproductive development, and may be influenced by reduced feeding in the spawning period. The low values of $C K$ (1.1) registered in S. japonicus peruanus females over $35 \mathrm{~cm}$ in fork length in the present study may be attributed, in part, to the intense spawning activity of the species during the 1992-1993 El Niño events. This may be confirmed by the fact that a remarkable increased in the Chub mackerel Gonadosomatic Index has been observed during El Niño events (DIOSES et al., 2002).

Nevertheless, further research using other reliable indicators is necessary to confirm the influence of El Niño phenomenon on the reproductive activity of $S$. japonicus peruanus.

\section{ACKNOWLEDGEMENTS}

The first author is grateful to the National Council for the Development of Science and Technology $(\mathrm{CNPq})$ for the fellowships (Grant: Proc. $\mathrm{N}^{\circ}$ 140023/03-8). We thank the "Instituto del Mar del Peru - IMARPE" for making available the material for supporting this study and for the use of its laboratories. The constructive comments of 2 anonymous reviewers greatly improved the manuscript.

\section{REFERENCES}

ALHEIT, S. Impact of climate variability on small pelagic fish stock - a comparative view. Investnes mar., Valparaiso, v. 30, n. 1, p. 175, 2002.

ANDA-MONTAÑEZ, J.A.; AMADOR-BUENROSTRO, A.; MARTÍNEZ-AGUILAr, S.; MUHLIA-ALMAZÁN, A. Spatial analysis of yellowfin tuna (Tunnus albacares) catches rate and its relation to El Niño and La Niña events in the eastern tropical Pacific. Deep-Sea Res., II, v. 51,p. 575-586, 2004.

ANDERSON, R.; GUTREUTER, S. Length, weight and associated structural indices. In: NIELSEN, L. A; JOHNSON, D. L. (Ed.) Fisheries techniques. Amer. Fish. Soc., 1983. p. 283-300.

ARANCÍBIA, H.; NEIRA, S. Does ENSO induce changes in recruitment of Horse mackerel (Trachurus symmetricus) and in the long-term trend of the trophic level of fishery landings in Central Chile? Investigación pesq., Santiago, v. 30, n. 1, p. 179-181, 2002.

ARANCÍBIA, H.; CUBILLOS, C.; REMMAGGI, J.; ALARCÓN, R. Determinación de la talla de madurez sexual y fecundidad parcial en la sardina común, Strangomera bentincki (Norman, 1936), del área del Talcahuano, Chile. Biologia pesq., v. 23 , p. 11-17, 1994.

ARRIAGA, L; COELLO, S. Escala de madurez para los principales peces pelágicos en aguas ecuatorianas. Cienc. Mar. Limnol., v. 2, n. 1, p. 69-78, 1984.

BORJA, A.; URIARTE, A. ; EGAÑA, J. Environmental factors and, recruitment of mackerel, Scomber scombrus L. 1758, along the north-east Atlantic coast of Europe. Fish. Oceanogr., v. 11, n.2, p. 116-177, 2002.

BUITRON, B.; PEREA, A. Estimación de la fecundidad parcial de la caballa (Scomber japonicus peruanus) a inicios de otoño 1998. Infmes Inst. Mar Perú, v. 135, p. 143-146, 1998.

CARAMANTÍN, H. Algunos aspectos reproductivos y su relación con el factor de condición de Scomber japonicus peruanus (Jordán y Hubb, 1925) (Teleostomi: Scombridae) en la zona norte y centro del litoral peruano durante 1990-1991. Tesis (Licenciado en Biología). Facultad de Ciencias Biológicas, Universidad Ricardo Palma de Lima, Perú, 1998. $105 \mathrm{p}$.

CARAMANTÍN, H. Efecto de la variabilidad ambiental en los aspectos reproductivos de la caballa Scomber japonicus peruanus (Jordán y Hubb, 1925) en el litoral peruano durante 1990-1998. Tese (Maestría). Facultad de Ingenieria, Universidad Nacional Federico Villarreal de Lima, Perú, 2001. 136 p.

CARAMANTÍN, H. Dinâmica populacional de Scomber japonicus peruanus (Jordán \& Hubb, 1925) (Teleostomi: Scombridae) no litoral peruano, no período de 1990-2003. Tese (Doutorado). Instituto Oceanográfico da Universidade de São Paulo, 2006. 148 p.

CARAMANTÍN-SORIANO, H.; VEGA-PÉREZ, L.A. \& NIQUEN M. Growth parameters and mortality rate of the Scomber japonicus peruanus (Jordán and Hubb, 1925) along the Peruvian coast, south Pacific. Braz. J. Oceanogr., v. 56, n. 3, p. 201-210, 2008. 
COLLETTE, B.; NAUEN, C. Species catalogue. United Nations Development Programme. FAO- Fish. Synop., v. 2, n. 125 , p. 55-65, 1983.

CLAEREBOUDT, M. R.; MCLLWAIN, J. L.; AL-OUFI, H. S.; AMBU-ALI, A. A. Patterns of reproduction and spawning of the kingfish (Scomberomorus commerson, Lacepede) in the coastal waters of the Sultanate of Oman. Fish. Res., v. 73, p. 273-282, 2005.

DIOSES, T.; DÁVALOS, R.; ZUZUNAGA, J. El Niño 1982-1983 and 1997-1998: Effects on Peruvian jack mackerel and Peruvian chub mackerel. Investnes mar. v. 30, n. 1, p. $185-187,2002$

ESCRIBANO, R.; HIDALGO, P.; FERNÁNDEZ, D Responses of zooplankton populations to the 1997/98 El Niño in the coastal upwelling zone off northern Chile: Is El Niño that bad? Investnes . mar., v. 30, n. 1, p. 109$111,2002$.

FAO. The State of World Fisheries and Aquaculture (SOFIA), Roma: Food and Agriculture Organization, 2007. 162 p. 2007.

GLUYAS-MILLÁN, M. G.; QUIÑONEZ-VELÁZQUEZ, C. Age, growth and reproduction of Pacific mackerel Scomber japonicus in the Gulf of California. Sci. Mar. v. 61, n. 3, p. 837-847, 1997.

HAY, D. E.; OUTRAM, D. N. Assessing and monitoring mature and gonad development in Pacific herring. Can. tech. Rept Fish. aquat. Sci., n. 998, 31 p., 1981.

IMARPE AND ITP. Compendio biológico tecnológico de las principales especies hidrobiológicas comerciales del Perú,, Callao, 1996. p. 39-41.

JIAN, C. Y.; CHENG, S. Y.; CHEN, J. C. Temperature and salinity tolerates of yellowfin sea bream, Acanthopagrus lotus, at different salinity and temperature levels. Aquacult. Res. , v. 34, n. 2. p. 175-185, 2003.

JOHANSEN, A. C. On the large spring-spawning sea-herring (Clupea harengus l.) in the north-west European waters. Medd. Fra. Komm. Hauunders, Ser. Fiskeri Bind, vol. 8, 1919.

KAINGE, P.; KJESBU, O.S.; THORSEN, A.; SALVANES, A.G. Merluccius capensis spawn in Namibian waters, but do M. paradoxus? African J. mar. Sci., v. 29, n. 3, p. 379-392, 2007.

KOTLYAR, A. N.; ABRAMOV, A. A. Some biological properties of Peruvian mackerel Scomber japonicus peruanus (Scombridae). J. Ichthyol., v. 22, n. 6, p. 91$101,1982$.

LIU, K. M.; HUNG, K. Y.; CHEN, C.T. Reproductive biology of the big eye Priacanthus macracanthus in the north-eastern waters off Taiwan. Fish. Sci.,v. 67, p. 1008-1014, 2001.

LU, H. J.; LEE, K. T.; LIN, H. L. Y.; LIAO, CH. H. Spatiotemporal distribution of yellowfin tuna Thипnиs albacares and bigeye Thunnus obesus in the Tropical Pacific Ocean in relation to large-scale temperature fluctuation during ENSO episodes. Fish. Sci., v. 67, p. 1046-105, 2001.

MACKIE, M.; LEWIS, P. Assessment of gonad staging systems and other methods used in the study of the reproductive biology of narrow-barred Spanish mackerel, Scomberomorus commerson, in Western Australia. Fish. Res. Rept. West. Aust., v. 136, p. 1-32, 2001.

MADDOCK, D. M.; Burton, M. P. M. Gross and histological observations of ovarian development and related condition change in American plaice. J. Fish Biol., v. 53, p. 928-944, 1998.

MCFARLANE, G. A.; SCHWEIGERT, J.; MACDOUGALL, L.; HRABOK, C. Distribution and biology of Pacific sardines (Sardinops sagax) off British Columbia, Canada. CalCOFI Rep., v. 46, p. 144-160, 2005.

MARTÍNEZ, C. F.; SALAZAR, C. Z.; BÖHM, G. S.; MENDIETA, J. C. V.; ESTRADA, C. M. Efectos del fenómeno El Niño 1982-1983 sobre los principales recursos pelágicos y su pesquería (Arica-Antofagasta). Investigación. pesq., Santiago, v. 32, p. 129-139, 1985.

MENDO, J. Edad, crecimiento y algunos aspectos reproductivos y alimenticios de la caballa, Scomber japonicus peruanus. Boln Inst. Mar Perú, v. 8, n. 4, p. 101-156, 1984.

MIÑANO, J.; CASTILLO, J. Primeros resultados de la investigación biológica pesquera de la "caballa" Scomber japonicus peruanus (Chimbote). Infmes Inst. Mar Perú, n. IM-84, 1971.

MORÓN, O. Características del ambiente marino frente a la costa peruana, Boln Inst. Mar Perú, v. 19, n. 1-2, p. 179-204, 2000.

MUNRO, A. D.; SCOTT, A. P.; LAM, T. J. Reproductive seasonality in teleosts: environmental influences. Boca Raton, FLA.: CRC Press, 1990. 254 p.

NARIMATSU,Y.; YAMANOBE, A.; TAKAHASHI, M. Reproductive cycle, age, and body size at maturity and fecundity of female willowy flounder Tanakius kitaharai. Fish. Sci., v. 73, p. 55-62, 2007.

NIIQUEN, M.; BOUCHON, M. Estadisticas de las pesquerias pelágicas en la costa peruana. Boln Inst. Mar Perú, 1995, 323 p.

NIIQUEN, M.; BOUCHON, M. Impact of El Niño of pelagic fisheries in Peruvian waters. Deep-Sea Res., II, v. 51, p. 563-574, 2004.

OLDEPESCA. Bases biológicas y marco conceptual para el manejo de los recursos pelágicos en el Pacífico Sur oriental. Doc. Pesca, n. 1, 1986. 181 p.

PALOMARES-GARCÍA, R.; MARTÍNEZ-LÓPEZ, A.; DE SILVA-DÁVILA， R.; FUNES-RODRÍGUEZ, R.; CARBALLIDO-CARRANZA, M.A.; AVENDAÑOIBARRA, R.; HINOJOSA-MEDINA, A.; LÓPEZIBARRA, G.A. Biological effects of El Niño 1997-98 on a shallow subtropical ecosystem: Bahia Magdalena, Mexico. Geof. intern.,v. 42, n. 3, p. 455-466, 2003.

PEÑA, N.; ALHEIT, J.; NAKAMA, M. E. Fecundidad parcial de la caballa del Perú (Scomber japonicus peruanus). Boln Inst. Mar Perú, v. 10, n. 4, p. 93-104, 1986.

PEÑA, N.; CARRASCO, S. Principales aspectos pesqueros y biológicos de los recursos anchoveta y sardina en los años de 1986 y 1987 en la costa peruana. Com. Perm. Pacifico Sur, 1989. p. 242-251.

PERROTA, R. G.; VIÑAS, M.; HERNÁNDEZ, D.; TRIGALI, L. Temperature conditions in the Argentine Chub mackerel (Scomber japonicus) fishing ground: implications for fishery management. Fish. Oceanogr., v. 10, n. 3, p. 275-283, 2001.

PLAZA, G.; SAKAJI, H.; HONDA, H.; HIROTA, Y.; NASHIDA, K. Spawning pattern and type of fecundity in relation to ovarian allometry in the round herring Etrumeus teres. Mar. Biol., v. 152, n. 5, p.1051-1064, 2007. 
RIASCOS, V. J. M. Effects of El Niño-Southern oscillation on the population dynamics of the tropical bivalve Donax dentifer from Malaga bay Colombian Pacific. Mar. Biol., v. 148, n. 6, p. 1283-1293, 2006.

SÁNCHEZ DE BENITES, G.; ÁLAMO, A.; FUENTES, H. Alteraciones en la dieta alimentaria de algunos peces comerciales por efecto del fenómeno El Niño. In: ARNTZ, W.; LANDA, A.; TARAZONA, J. (Ed.). El Niño su impacto en la fauna marina. Boln Inst. Mar Perú 1985. p. 135-142. Vol. especial.

SANTANDER, H.; FLORES, R. Los desoves y distribución larval de cuatro especies pelágicas y sus relaciones con las variaciones del ambiente marino frente al Perú. FAO Fish. Rept., v. 291, n. 3, p.835-867, 1983.

SANTANDER, H.; ZUZUNAGA, J. Cambios en algunos componentes del ecosistema marino frente al Perú durante el fenómeno El Niño 1982-1983. Rev. Com. perm. Pacífico Sur, v. 15, p. 311-331, 1984.

SILVA, G. C.; LEAL DE CASTRO, A. C.; GUBIANI, E.A. Estrutura populacional e indicadores reprodutivos de Scomberomorus brasiliensis Collette, Russo e ZavalaCamin, 1978 (Perciformes: Scombridae) no litoral ocidental maranhense. Acta Sci. Biol.,v. 27, n. 4,p. 383389, 2005.

SOUZA-CONCEIÇÃO, J. M.; RODRIGUES-RIBEIRO,M.; CASTRO-SILVA, M. A. Dinâmica populacional, biologia reprodutiva e o ictioplâncton de Cetengraulis edentulus Cuvier (Pisces, Clupeiformes, Engraulidae) na enseada do Saco dos Limões, Florianópolis, Santa Catarina, Brasil. Rev. Bras. Zool., v. 22, n. 4, p. 383$389,2005$.
VAZZOLER, A. E. Biologia da reprodução de peixes teleósteos: teoria e prática. Maringá: Universidade Estadual de Maringá , 1996. 169 p.

WEST, G. Methods of assessing ovarian development in fishes: a review. Aust. J. mar. Freshwat. Res., v. 41, p. 199-222, 1990.

WILCZACK, J. M.; LEBEM, R. R.; MCCOLLUM, D. S. Upper-ocean thermal structure and heat content off the US West Coast during the 1997-1998 El Niño event based on AXBT and satellite altimetry data. Prog. Oceanogr., v. 74, p. 48-70, 2007.

WOOTTON, R.J. Ecology of teleost fishes. Londres: Kluwer Academic, 1998. 404 p.

ZAR, J. H. Biostatiscal analysis. 4th ed. Prentice Hall Upper Saddle RFiver, NJ: Prentice-Hall, 1999. 663 p.

ZUZUNAGA, J. Cambios del equilibio poblacional entre la anchoveta (Engraulis ringens) y la sardina (Sardinops sagax) en el sistema de afloramiento frente al Perú. In: Arntz, W.; Landa, A.; Tarazona, J., (Ed). El Niño. Su impacto en la fauna marina. Boln Inst. Mar Perú p. 107-117, 1985. Vol. especial.

(Manuscript received 13 November 2007; revised 31 March 2008; accepted 15 June 2009) 